\title{
Tourism and Livelihood Sovereignty: A Theoretical Introduction and Research Agenda for Arctic Contexts
}

\author{
Ryan S. Naylor ${ }^{1, *(1)}$ and Carter A. Hunt ${ }^{2}$ (D) \\ 1 Department of Recreation, Park and Tourism Management, Pennsylvania State University, University Park, \\ State College, PA 16802, USA \\ 2 Department of Recreation, Park and Tourism Management, and Anthropology, Pennsylvania State University, \\ University Park, State College, PA 16802, USA; cah59@psu.edu \\ * Correspondence: rsn16@psu.edu
}

check for

updates

Citation: Naylor, R.S.; Hunt, C.A. Tourism and Livelihood Sovereignty: A Theoretical Introduction and Research Agenda for Arctic Contexts. Societies 2021, 11, 105. https:// doi.org/10.3390/soc11030105

Academic Editors: Iulia Cristina Muresan, Horațiu Felix Arion and Diana Elena Dumitraș

Received: 4 August 2021

Accepted: 24 August 2021

Published: 31 August 2021

Publisher's Note: MDPI stays neutral with regard to jurisdictional claims in published maps and institutional affiliations.

Copyright: (C) 2021 by the authors Licensee MDPI, Basel, Switzerland. This article is an open access article distributed under the terms and conditions of the Creative Commons Attribution (CC BY) license (https:/ / creativecommons.org/licenses/by/ $4.0 /)$.

\begin{abstract}
The need to understand how Arctic coastal communities can remain resilient in the wake of rapid anthropogenic change that is disproportionately affecting the region-including, but not limited to, climate instability and the increasing reach of the tourism sector-is more urgent than ever. With sovereignty discourse at the forefront of Arctic sustainability research, integrating existing sovereignty scholarship into the tourism literature yields new theory-building opportunities. The purpose of this paper is to conceptually analyze the implications of (1) applying both theoretical and social movement ideas about sovereignty to tourism research in Arctic coastal communities, (2) the extent to which these ideas revolve around livelihood sovereignty in particular, (3) the influence of existing tourism development on shifting livelihood sovereignty dynamics, and, ultimately, (4) the opportunities for further research that enables more sovereign sustainable tourism development across the Arctic region. Given the northward march of the tourism frontier across Arctic regions, an exploration of tourism's influence on sovereignty presents a timely opportunity to advance theory and promote policy incentives for forms of tourism development that are more likely to yield sustainable and resilient outcomes for Arctic communities.
\end{abstract}

Keywords: sovereignty; livelihoods; community development; sustainability; cruise tourism

\section{Introduction}

The Arctic region, typically defined as the region lying to the north of the Arctic Circle at $66^{\circ} 33^{\prime} \mathrm{N}$ [1], is one of the most rapidly changing, institutionally complex, and culturally diverse regions in the world [2,3], and Arctic coastal communities are some of the most vulnerable to anthropogenic change [4]. Coasts will experience a disproportionate amount of biophysical change driven by both climate instability and growth-driven economic activity, for which Arctic governance has not kept pace [5]. Tourism is one hallmark characteristic of the "Great Acceleration" of anthropogenic impact across the planet [6], and its influence as a driver of social and environmental disturbance in Arctic coastal regions is only growing as natural-resource-based livelihoods decline (for elaboration of these various impacts, see, for example, [7-11]). Yet, little remains known about how the growth of the Arctic tourism sector impacts human-environmental relationships and intersects with locallevel governance or how it influences a community's power over the natural resources upon which its livelihoods are dependent. Recognizing the inevitability of tourism growth into further regions of the Arctic, an improved understanding of these issues where they are already occurring is essential for fostering sustainable forms of development centered on the wellbeing of the diverse populations and ecosystems in the region.

One promising line of social science research that addresses cherished values as they manifest in local-level governance and decision-making has unfolded around the concept of sovereignty. Conventional notions of sovereignty, where power lies within the nation-state [12,13], have more recently given way to both research and activism that 
have extended ideas of sovereignty from national and international diplomatic relations to various locally grounded struggles for Indigenous, cultural, food, natural resource, and conservation sovereignty. Academic discourse has much to gain from further study of how ideas of sovereignty manifest in and beyond specific sovereignty movements since such ideas can facilitate the formation of collective identity and action, thereby providing greater opportunity for historically disenfranchised individuals to overcome powerful differentials and seek greater wellbeing [14,15]. An opportunity currently exists to distill elements from numerous social science approaches to sovereignty for application to tourism studies and to craft a broader theoretical framing of livelihood sovereignty (i.e., autonomous, locally controlled, and socio-culturally appropriate forms of sustainable community development) to encapsulate system dynamics when new forms of development are introduced. The application of such a framing to an analysis of institutional arrangements and governance in Arctic coastal communities will determine how individuals and communities strive for self-determination - in some cases successfully and in some cases less successfully-amidst the dynamic anthropogenic changes characterizing the region.

\subsection{Purpose and Relevance}

While sovereignty has spurred scholarship in other academic disciplines, such as rural sociology, geography, and political science, and has sparked international movements, the objective of this paper is to introduce and catalyze a discussion of sovereignty within tourism studies, particularly for areas experiencing increasing tourism mobilities, such as the Arctic. Therefore, the purpose of this paper is to conceptually analyze the implications of (1) applying ideas of both theoretical and social movements about sovereignty for Arctic coastal communities, (2) the extent to which these ideas revolve around livelihood sovereignty, (3) the influence of market forces—stemming from tourism in particular-on shifting these livelihood sovereignty dynamics, and, ultimately, (4) providing theoretical guidance on existing opportunities to promote more sovereign forms of sustainable tourism development across the Arctic region. Briefly synthesizing and applying the broader sovereignty scholarship, this review explores the various influences that the growing tourism sector has on local institutional arrangements and decision making, as well as how they affect the relationship between local residents and the natural resources upon which both subsistence and market-based livelihood security have traditionally hinged in Arctic regions.

In doing so, our discussion seeks to query the existing theory for theoretical answers to several overarching research questions. First, how are the various dimensions of sovereignty shaping, and being shaped by, the growing economic and political influence of the tourism sector? Also, how is anthropogenic biophysical change further influencing these dynamics? Finally, what opportunities exist for theorizing how sustainable development of the region could be reconceptualized to promote not only livelihood security but also characteristics of livelihood sovereignty (i.e., greater political agency, autonomy, and self-determination)? Given that sovereignty scholarship has seen limited application in tourism studies despite the decolonial turn currently underway across the social sciences, this writing provides a needed nudge to link the field of tourism studies with both scholarship and activism pertaining to sovereignty.

If individuals do not have decision-making authority over the natural and cultural resources necessary for their livelihood and wellbeing, tourism-related sustainable development and environmental conservation efforts are unlikely to succeed [16-19]. Despite the recognition of tourism as an essential tool for conservation and community development [20], current Arctic cruise tourism governance is unable to ensure the protection of the pristine natural environments and the cultural practices upon which the tourism industry relies [7], nor does it address power differentials that influence how communities adapt over time [11]. If a new understanding and application of livelihood sovereignty theory can account for how the relationships between individuals with different levels of power change as a consequence of cruise tourism development, then proactive adaptive 
management of these relationships in Arctic coastal communities becomes far more likely. Establishing a strong theoretical basis for such work is extremely timely, as the issues being experienced within the sub-Arctic regions will become increasingly important as the Arctic continues to warm, the biophysical barrier of sea ice continues to retreat, and various forms of tourism development continue to march northward into new regions of the Arctic [5,21,22].

\subsection{Theoretical Background}

Ideas related to sovereignty have manifested across numerous social science disciplines. While traditional notions of sovereignty revolved around territorial, political, and diplomatic recognition, the current treatment of sovereignty in both social science discourse and associated social movements has evolved greatly to address issues that include, but are not limited to, Indigeneity, culture, conservation and resource management, and, most extensively, food systems. This theoretical pedigree of sovereignty is briefly reviewed here, several dimensions of sovereignty are described, and the livelihood sovereignty framing is articulated to guide this study of tourism-related impacts on Arctic coastal communities.

\subsubsection{Foundational Views of Sovereignty}

The origin of sovereignty in international discourse is often attributed to the rise of nation-states and the early articulation of the concept in the 1648 Peace of Westphalia. These early views of sovereignty characterized the nation-state as a supreme authority capable of autonomous decision-making processes without external interference, and as such, they enabled its authority to be recognized as such by other sovereign actors [13]. Though debates have arisen as to whether sovereignty ideals can exist given an acknowledged role of markets in creating interdependencies among nation-states [12], conventional views of sovereignty remain central to modern discourse on international relations. In parallel, other scholars argued that states are participants within larger cultural frameworks and that sovereignty is merely a social construct, one existing independently of external recognition (e.g., [23]). This view of sovereignty moves the analytical lens from relationships between nations to far broader manifestations of power differentials that are continuously shaped through social processes [24]. Within this expanded conceptualization, sovereignty is no longer bound by juridical or territorial characteristics, but instead becomes a more relational concept characterizing individuals and institutions in relation to one another [25]. This conceptual expansion of sovereignty opened the door to more diverse applications of the concept in theory and practice.

In recent decades, sovereignty has seen many new applications in and outside of academia, manifesting in numerous contexts where imbalances of socioeconomic power, local control and autonomy, and access to resources of value exist. International sovereignty movements have arisen to contest these power imbalances, including but not limited to global struggles to promote food sovereignty and regional efforts to facilitate Indigenous sovereignty $[14,26]$. Food sovereignty is strongly associated with the international peasant movement, La Via Campesina, which, at the 1996 World Food Summit, proposed food sovereignty as an alternative paradigm to the food security discourse. Whereas the food security paradigm is based on a region's ability to produce for the purpose of global trade [27], food sovereignty emphasizes local control of agricultural production systems and rejects the value judgments of those in power $[15,28]$. By focusing on political agency, autonomy, and self-reliance at the local scale [15], this conceptual approach situates security as a necessary but insufficient step towards sovereignty [29]. It would therefore logically follow to theorize that livelihood sovereignty, not livelihood security, should likewise be the ultimate goal of any effort to ensure sustainable and resilient development of Arctic communities.

The Indigenous sovereignty movement Idle No More directly confronted conventional nation-state views of sovereignty by challenging the Canadian national government's claims to land and resources claimed by Indigenous residents [26]. Though this movement 
seeks to enfranchise the Indigenous polity to claim governing authority over traditional territories [30], its objectives are not limited to simply securing land tenure. Issues of access, decision making, control over natural resources, and the educational practices necessary for maintaining a shared cultural identity are centrally featured [31,32]. The movement's calls for Indigenous sovereignty have strengthened calls for both cultural sovereignty [33] and intellectual sovereignty, broadly conceived [34,35]. Contemporary sovereignty theory has thus adapted to address issues up and down the nested levels of social analysis (e.g., Indigenous vs. cultural vs. intellectual sovereignty), as well as across highly related, if a bit more distinct, thematic realms (e.g., food vs. data sovereignty).

\subsubsection{Addressing the Dimensionality of Sovereignty}

Given the explosion of theory in recent decades around multiple forms of sovereignty and multiple sovereignty movements (e.g., [15,25,36,37]), as well as the broad rejection of equilibrium theory in favor of complex and dynamic systems perspectives across all scientific disciplines [38,39], it is necessary to recognize the fluid and subjective nature of sovereignty:

"Sovereignty is not an extraneously existing object but is a living process, it foregrounds the conscientious building and maintaining of relationships between people, institutions, technologies, ecosystems, and landscapes across multiple scales. It provokes more attention to the how of systemic change than to the what." [25] (p. 483)

Individuals, institutions, and communities are in constant states of negotiation of fluid sovereignty dynamics within their individual and collective decision-making processes. Such decisions will be regulated by the level of control in relation to other actors, including those with greater influence over resources such as critical knowledge, culture, and natural resources. Furthermore, levels of control are not limited to sociopolitical interaction between people and institutions, but anthropogenic disturbance to ecosystems can also influence human-environment relationships and the extent of natural capital one has to draw upon to support wellbeing. Sovereignty theory strives to account for the ways that sociopolitical and economic factors (e.g., tourism development), as well as environmental factors (e.g., climate change), influence individual or community wellbeing.

Debate over the utility of sovereignty theory has drawn important attention to its relationship to the human and civil rights discourse, implying that sovereignty can only be granted by dominant institutions whose interests stand in direct opposition to any relinquishing of power $[15,40]$. While the theoretical malleability of sovereignty is seen by some as inhibiting its ability to promote solutions (e.g., [31]), it ultimately revolves around highly subjective value judgments regarding the consequences of economic and political power differentials and what constitutes a viable and long-term human-environment relationship $[33,36,41]$. Thus, for many scholars, the value of sovereignty theory stems from the powerful means that it provides to frame conversations about appropriate forms of development, to create spaces of agreement that unite people of different cultural identities and socioeconomic backgrounds, and to enable collective action in the interest of confronting deep-seated inequities that often inhibit shared views of what appropriate forms of sustainable development are [14]. Documenting such shared meanings of sovereignty can help anticipate conflicts, frame messaging and policies, and facilitate greater collective action in the interest of sustainable and resilient community development.

\subsubsection{Tourism, Sovereignty, and Livelihood Sovereignty}

As a fundamental characteristic of the Great Acceleration of the Anthropocene, tourism has evolved into a massive driver of social and environmental change $[6,42,43]$. As such, it has enormous potential to either enhance or inhibit forms of sovereignty, such as local control of natural resources [44], cultural preservation [10,11,17,45], and political empowerment $[46,47]$. However, despite its clear overlap with these issues of interest, sovereignty theory has seen limited application in tourism studies. Limited exceptions include research 
exhibiting conventional notions of sovereignty to address tourism's influence on the exchange of land in polar regions [48], and to draw attention to power differentials between local and non-local actors that lead to loss of sovereignty for traditional inhabitants [49]. In other cases, however, scholars have noted that tourism can provide Indigenous peoples with opportunities to retain traditional knowledge and ways of being, or to revive the practices at the core of cultural sovereignty [50-52].

To holistically understand how a new form of development (i.e., tourism) shifts the control of valued resources, rural studies scholars have called for the extension of food sovereignty to a more inclusive concept of livelihood sovereignty [53-55]. Livelihood sovereignty refers to the enhanced levels of local resident control and influence over management institutions and decision-making regarding the persistence of valued traditional practices, how new production opportunities are integrated into socio-ecological systems, and how local community wellbeing is perpetuated over time. Just as one can be food secure in prison [15], economic security is not the end itself, and it is insufficient for achieving the freedom necessary to live the lives that individuals have reason to value [56]. Echoing food sovereignty literature, livelihood security is a necessary, but not sufficient, condition for livelihood sovereignty. Accounting for this distinction requires careful attention to additional subjective, locally determined dimensions of sovereignty that can co-exist and nest within other forms of sovereignty. Combining the idea of "livelihoods," as the multi-dimensional means of making a living $[57,58]$, and the multiple shared meanings of sovereignty, a focus on livelihood sovereignty allows for a more grounded and subjective understanding of how new forms of (tourism) development integrate within existing subsistence and market-based livelihoods. A livelihood sovereignty lens helps explain why new avenues of economic security via tourism development are not always socially accepted and, in some cases, can even lead to antagonism towards the tourism sector [59].

The relationships between individuals, communities, institutions, and resources they value (e.g., knowledge, cultural heritage, natural resources) are directly affected by tourism development and its shifting dynamics over time [16,59-61]. Though tourism scholars have yet to approach their work through the lens of livelihood sovereignty, findings in this field collectively support the contention that the economic impacts of tourism (e.g., employment and income) are necessary, but not sufficient, conditions for promoting the social and environmental aspects of sustainable community development $[20,42,62,63]$. That is, the findings to date are highly consistent with the notion that livelihood security is a necessary, but not sufficient, condition for livelihood sovereignty, and that the greater presence of the latter is likely to be associated with more favorable social and environmental consequences of tourism. Table 1 provides preliminary examples of the ways that existing sovereignty scholarship could be linked to tourism scholarship.

Table 1. Definitions of key forms of sovereignty and examples of their relation to tourism development.

\begin{tabular}{cll}
\hline Term & \multicolumn{1}{c}{ Sample Definition } & \multicolumn{1}{c}{ Implications for Tourism Research } \\
\hline Indigenous Sovereignty & $\begin{array}{l}\text { "The authority and obligation of people } \\
\text { within an indigenous polity to determine } \\
\text { the extent and nature of their governing } \\
\text { authority with regard to their territories } \\
\text { and one another" [30] (p. 239). }\end{array}$ & $\begin{array}{l}\text { "Sovereignty must limit } \\
\text { hospitality"-implies political } \\
\text { empowerment of Native Hawaiians } \\
\text { enabled by visualizing occupation and } \\
\text { allowing tourists to contemplate their role } \\
\text { in colonialization [49] (p. 680). }\end{array}$ \\
& $\begin{array}{ll}\text { "The right of peoples to healthy and } \\
\text { culturally appropriate food produced } \\
\text { through ecologically sound and sustainable } \\
\text { methods, and their right to define their } \\
\text { own food and agriculture systems" [64] } \\
\text { (para 3). }\end{array}$ & $\begin{array}{l}\text { Using tourism to highlight traditional food } \\
\text { systems in ways that promote community } \\
\text { empowerment [65]. }\end{array}$ \\
\hline
\end{tabular}


Table 1. Cont.

\begin{tabular}{|c|c|c|}
\hline Term & Sample Definition & Implications for Tourism Research \\
\hline Cultural Sovereignty & $\begin{array}{l}\text { "The effort of Indian nations and Indian } \\
\text { people to exercise their own norms and } \\
\text { values in structuring their collective } \\
\text { futures" [33] (p. 196). }\end{array}$ & $\begin{array}{l}\text { Self-commodification, or "a set of beliefs } \\
\text { and practices in which an individual } \\
\text { chooses to construct a marketable identity } \\
\text { product while striving to avoid alienating } \\
\text { him- or herself" [50] (p. 381). }\end{array}$ \\
\hline
\end{tabular}

Tourism scholars should enter data-sharing

"Indigenous data sovereignty is the right of Indigenous people, including AIAN agreements, allow for local ownership of (American Indian and Alaska Native), to material and data, inclusion of local and

Data Sovereignty govern data collection, ownership, and) application of their own data" [35] (p. 728). Indigenous peoples as coauthors, and support for the restriction of data (no known citations in the tourism literature; see [35] for broader guidelines).

Enable Arctic communities to conduct their

"a way of recognizing the important influences of economics, gender, and the Intellectual Sovereignty politics of publishing and the academy, but would not automatically dismiss someone because of such influences" [66] (p. 11). own research, as stated here: "We have seen research principles go from research on Inuit to research with Inuit, but it is high time we witnessed research by Inuit for Inuit" [67] (p. 29). (no known citations in the tourism literature).

The enhanced levels of local resident control and influence over management institutions and decision making regarding the persistence of valued traditional practices, how new production opportunities are integrated into socio-ecological systems, and how local community wellbeing is perpetuated over time. *

Local control over tourism development leading to agency, autonomy, and self-reliance over tourism livelihoods. (no known citations in the tourism literature).

* Adapted by the authors from [53-55].

\section{A Research Agenda for Tourism and Livelihood Sovereignty}

Given the vast expansion of the frontier of tourism across Arctic regions in particular, including the opening of new marine access as sea ice gives way to global warming, an exploration of tourism's influence on sovereignty is a timely opportunity to advance theory and, in turn, promote further research and policy incentives for forms of tourism development that are more likely to yield sustainable and resilient outcomes for Arctic communities. In light of the literature reviewed above, the following paragraphs provide several suggestions for future empirical work on the relationship between tourism and livelihood sovereignty.

To begin, research is needed to determine the issues around which sovereignty is centered for residents in Arctic coastal communities. The material reviewed above suggests that sovereignty will have shared meanings among and within communities in the study region, but such meanings are likely to diverge based on employment and income (i.e., livelihood security), as well as the levels of perceived autonomy and control that community residents have with respect to their livelihoods (i.e., livelihood sovereignty). Control over their natural resources, traditional ways of life, and the production of knowledge will be associated with more sovereign livelihoods. To better understand the nature of ideas associated with sovereignty and how they are organized in relation to tourism, one fruitful approach to future analyses would be the suite of techniques associated with cultural domain and cultural consensus analyses [68-70]. Though they are common in anthropology, such techniques have seen only minimal application in tourism studies [71]. Building off of basic qualitative data collection techniques (e.g., free listing and pile sorting), these techniques rely on consensus theory to determine cultural models and "answer keys," how groups differ within and between communities with respect to these shared cultural 
models, how any given individual differs from shared cultural models, and other underlying dimensions of sovereignty as espoused by local residents. Given that the proposed application of sovereignty theory to tourism studies is novel here, the underlying dimensions of the concept are unknown. Furthermore, with the power of peasant movements, which often result from their ability to unite under a shared cause (Martínez-Torres and Rosset, 2010), such techniques that explore presence—or absence—of consensus around sovereignty will help researchers more fully conceptualize livelihood sovereignty.

A second thread of research will then be needed to empirically determine what the specific influence of tourism on livelihood sovereignty in Arctic coastal communities is. If we accept that livelihood security is a necessary but insufficient condition for livelihood sovereignty, as elaborated above, it would then be expected that a greater magnitude of tourism development alone (e.g., more visitors, more cruise ships, more employment) will not necessarily be associated with favorable views of tourism-related development. Given that the power of sovereignty lies in its ability to unite people under shared meanings, greater levels of wellbeing gained only by those directly involved in the industry will not transcend into community-wide sentiments. In contrast, greater levels of participation and autonomy in decision making regarding valued assets (e.g., knowledge, cultural heritage, natural resources), which are characteristics of livelihood sovereignty, will remain associated with favorable views of tourism-related outcomes in a community. Research that empirically demonstrates linkages between tourism and these desired community outcomes will be essential. While further ethnographic and survey-based work can contribute to such research, one particularly valuable analytical approach could include a social network analysis focused on identifying how social learning and information flows yield common understandings of tourism development. Determining where both direct and indirect connections to tourism are present can help identify opportunities to improve network governance of community actors in ways that ensure equitable access to and distribution of tourism-related benefits throughout the community. The intangible nature of sovereignty dictates that approaches are capable of capturing notions of equity, justice, and power (e.g., political ecology, human geography, and environmental anthropology) will therefore be essential.

Beyond understanding the dimensions of sovereignty and the ways that they are influenced by tourism, research will be needed to assess how current and anticipated climate dynamics influence tourism-related livelihood sovereignty in Arctic coastal communities. That is, how are various livelihood sovereignties interwoven within and between communities, and how will ongoing anthropogenic disturbances differentially affect livelihood dynamics? The evidence is clear that extreme weather events will occur more frequently and that natural processes supporting the provision of resources and ecosystem services will be directly influenced by these events (e.g., disrupted salmon spawning). If tourism is to be a force for resilient community development, forms of tourism that supplementrather than displace - traditional subsistence and market-based livelihoods (i.e., those that promote sovereignty and not just security) will therefore need to support not only socioeconomic resilience, but also the maintenance of valued cultural heritage. Given that tourism is not a homogenous activity but rather can exist along several dimensions (i.e., small/large, responsible/irresponsible), ethnography will continue to be a valuable methodological approach to understanding the lived experience of communities engaging in different forms of tourism while dealing with these anthropogenic environmental transitions. Ethnography's emphasis on capturing emic views of local residents will be essential for determining the extent to which sovereignty outcomes, as defined locally, result from tourism development, be it in cruises to southeast Alaska's Inside Passage, the glaciers of Greenland, or Siberia's Lake Baikal.

With greater understanding of meanings of sovereignty and how it is influenced by local and global change, applied research will still be needed to determine how greater levels of sovereignty can be achieved via responsible tourism development in Arctic coastal communities. Because the sovereignty of Arctic coastal communities is nested within 
local, regional, state, native, and federal governance structures, conflicts over the production of knowledge, traditional ways of life, and natural resources can be anticipated at any time that tourism development occurs in ways that do not promote locally preferred forms of livelihood sovereignty. Promoting these outcomes will be central to enabling selfdetermination, a necessary precursor to the long-term sustainability and resilience of Arctic coastal communities. Given the role of historical relations in contemporary determinations of sovereignty, it will remain essential to capture the temporal determinants of sovereignty. It is proposed that future research should rely on transdisciplinary approaches that form true collaborations with Arctic coastal communities. As detailed in the Interagency Arctic Research Policy Committee (IARPC) principles for conducting research in Arctic communities, any tourism research agenda must likewise task itself with an iterative research approach that seeks to develop lasting connections with Arctic community members for the purposes of facilitating their transition from a status as victims of external exploitation (including via research that fails to respect intellectual and data sovereignty) to empowered communities that are capable of conducting their own applied research in the interest of greater sovereignty across all sectors.

\section{Conclusions}

The need to understand how Arctic coastal communities can remain resilient in the wake of rapid anthropogenic change that is disproportionately affecting the regionincluding but not limited to climate instability and the increasing reach of the tourism sector-is more urgent than ever. Social science can bring valuable theoretical and conceptual lenses through which to view how Arctic residents and communities confront the magnitude and complexity of the social, economic, and political changes underway in the region. This research builds upon a productive line of social science theory to elaborate on nascent articulations of the concept of livelihood sovereignty. By identifying key issues within the broader sovereignty literature, several potential links to existing tourism-related literature, as well as to new lines of research in Arctic tourism, have been identified. The preliminary research agenda offered here only scratches the surface of potential engagement with the vast writings on sovereignty in recent years, yet it is precisely the vastness of that literature that necessitates this call for further awareness of sovereignty among tourism scholars and its integration into future tourism research, particularly in Arctic contexts.

Indeed, the ideas of livelihood sovereignty put forth here are motivated by the recognition that increased pressures on rural communities and their livelihoods in the Arctic region, including ones that emanate from expanded tourism, require the extension of analytical concepts beyond existing formulations of economic development focused on livelihood security. It is only through enhanced levels of local resident control over how new production opportunities (e.g., tourism) are integrated into local socioeconomic systems and, thus, how local communities' wellbeing is perpetuated over time that resilient and sustainable development can be achieved. With sovereignty discourses (e.g., Indigenous, cultural, and food sovereignty) at the forefront of Arctic sustainability research [72-74], the attention drawn to these issues here will initiate new empirical explorations and promote new theory building with respect to the ways that this essential element of resilient and sustainable community development can be facilitated with more responsible forms of tourism development across Arctic regions and beyond.

Author Contributions: Both authors contributed equally to the preparation of this manuscript. Both authors have read and agreed to the published version of the manuscript.

Funding: This research received no external funding.

Data Availability Statement: Not applicable.

Acknowledgments: The authors wish to thank Theodore Alter and B. Derrick Taff for their helpful comments on earlier drafts of these materials.

Conflicts of Interest: The authors declare no conflict of interest. 


\section{References}

1. Arctic Centre. Basic Information about the Arctic. Available online: https://www.arcticcentre.org/EN/arcticregion (accessed on 5 August 2021).

2. Fakhri, M. Gauging us and eu Seal Regimes in the Arctic against Inuit Sovereignty. In The European Union and the Arctic; Brill I Nijhoff: Leiden, The Netherlands, 2017; pp. 200-235, ISBN 9789004349179.

3. Pachauri, R.K.; Allen, M.R.; Barros, V.R.; Broome, J.; Cramer, W.; Christ, R.; Church, J.A.; Clarke, L.; Dahe, Q.; Dasgupta, P.; et al. Climate Change 2014: Synthesis Report; Contribution of Working Groups I, II and III to the Fifth Assessment Report of the Intergovernmental Panel on Climate Change; IPCC: Geneva, Switzerland, 2014; ISBN 9291691437.

4. Pörtner, H.-O.; Roberts, D.C.; Masson-Delmotte, V.; Zhai, P.; Tignor, M.; Poloczanska, E.; Mintenbeck, K.; Nicolai, M.; Okem, A.; Petzold, J. IPCC Special Report on the Ocean and Cryosphere in a Changing Climate; IPCC: Geneva, Switzerland, 2019 ; Volume 1.

5. Meredith, M.; Sommerkorn, M.; Cassotta, S.; Derksen, C.; Ekaykin, A.; Hollowed, A.; Kofinas, G.; Mackintosh, A.; MelbourneThomas, J.; Muelbert, M.M.C. Polar Regions. In IPCC Special Report on the Ocean and Cryosphere in a Changing Climate; IPCC: Geneva, Switzerland, 2019; pp. 203-320.

6. Steffen, W.; Broadgate, W.; Deutsch, L.; Gaffney, O.; Ludwig, C. The trajectory of the anthropocene: The great acceleration. Anthr. Rev. 2015, 2, 81-98. [CrossRef]

7. Dawson, J.; Johnston, M.E.; Stewart, E.J. Governance of arctic expedition cruise ships in a time of rapid environmental and economic change. Ocean Coast. Manag. 2014, 89, 88-99. [CrossRef]

8. Johnston, M.; Dawson, J.; De Souza, E.; Stewart, E.J. Management challenges for the fastest growing marine shipping sector in Arctic Canada: Pleasure crafts. Polar Rec. 2017, 53, 67-78. [CrossRef]

9. Scott, D.; Hall, C.M.; Gössling, S. A report on the Paris Climate Change Agreement and its implications for tourism: Why we will always have Paris. J. Sustain. Tour. 2016, 24, 933-948. [CrossRef]

10. Stewart, E.J.; Dawson, J.; Howell, S.E.L.; Johnston, M.E.; Pearce, T.; Lemelin, H. Local-level responses to sea ice change and cruise tourism in Arctic Canada's Northwest Passage. Polar Geogr. 2013, 36, 142-162. [CrossRef]

11. Stewart, E.J.; Dawson, J.; Johnston, M. Risks and opportunities associated with change in the cruise tourism sector: Community perspectives from Arctic Canada. Polar J. 2015, 5, 403-427. [CrossRef]

12. Bull, H. The Anarchical Society; Columbia University Press: New York, NY, USA, 1977; ISBN 0230393403.

13. Hobson, J.M.; Sharman, J.C. The enduring place of Hierarchy in world politics: Tracing the social logics of Hierarchy and political change. Eur. J. Int. Relat. 2005, 11, 61-98. [CrossRef]

14. Martínez-Torres, M.E.; Rosset, P.M. La ví a campesina: The birth and evolution of a transnational social movement. J. Peasant Stud. 2010, 37, 149-175. [CrossRef]

15. Patel, R. What does food sovereignty look like? J. Peasant Stud. 2009, 36, 663-706. [CrossRef]

16. Buckley, R. Sustainable tourism: Research and reality. Ann. Tour. Res. 2012, 39, 528-546. [CrossRef]

17. Stronza, A.L.; Gordillo, J. Community views of ecotourism. Ann. Tour. Res. 2008, 35, 448-468. [CrossRef]

18. Nunkoo, R.; Ramkissoon, H. Power, trust, social exchange and community support. Ann. Tour. Res. 2012, 39, 997-1023. [CrossRef]

19. Hunt, C.A.; Durham, W.H.; Driscoll, L.; Honey, M. Can ecotourism deliver real economic, social, and environmental benefits? A study of the Osa Peninsula, Costa Rica. J. Sustain. Tour. 2015, 23, 339-357. [CrossRef]

20. Stronza, A.L.; Hunt, C.A.; Fitzgerald, L.A. Ecotourism for Conservation? Annu. Rev. Environ. Resour. 2019, 44, 229-253. [CrossRef]

21. Cerveny, L.K. Tourism and Its Effects on Southeast Alaska Communities and Resources: Case Studies from Haines, Craig, and Hoonah, Alaska; DIANE Publishing: Portland, OR, USA, 2005. [CrossRef]

22. Kruger, L. Community and landscape change in southeast Alaska. Landsc. Urban Plan. 2005, 72, 235-249. [CrossRef]

23. Strang, D. Contested sovereignty: The social construction of colonial imperialism. Cambridge Stud. Int. Relat. 1996, 46, 22-49.

24. Stepputat, F. Formations of Sovereignty at the Frontier of the Modern State. Confl. Soc. 2016, 1, 129-143. [CrossRef]

25. Iles, A.; Montenegro de Wit, M. Sovereignty at What Scale? An Inquiry into Multiple Dimensions of Food Sovereignty. Globalizations 2015, 12, 481-497. [CrossRef]

26. Barker, A.J. 'A Direct Act of Resurgence, a Direct Act of Sovereignty': Reflections on Idle No More, Indigenous Activism, and Canadian Settler Colonialism. Globalizations 2015, 12, 43-65. [CrossRef]

27. McMichael, P. Global Development and the Corporate Food Regime; Emerald Group Publishing Limited: Bingley, UK, 2005; ISBN 0762312505.

28. Desmarais, A.A. The Vía Campesina: Consolidating an international peasant and farm movement. J. Peasant Stud. 2002, 29, 91-124. [CrossRef]

29. Via Campesina. The Right to Produce and Access to Land. Available online: http://safsc.org.za/wp-content/uploads/2015/09/ 1996-Declaration-of-Food-Sovereignty.pdf (accessed on 10 May 2021).

30. Cattelino, J.R. The double bind of American Indian need-based sovereignty. Cult. Anthropol. 2010, 25, 235-262. [CrossRef]

31. Corntassel, J.J.; Primeau, T.H. Indigenous sovereignty and international law: Revised strategies for pursuing self-determination. Hum. Rights Q. 1995, 17, 343-365.

32. Prinsen, G.; Blaise, S. An emerging “Islandian” sovereignty of non-self-governing islands. Int. J. 2017, 72, 56-78. [CrossRef]

33. Coffey, W.; Tsosie, R. Rethinking the tribal sovereignty doctrine: Cultural sovereignty and the collective further of Indian nations. Stanford Law Pol. Rev. 2001, 12, 191-221. 
34. Latulippe, N.; Klenk, N. Making room and moving over: Knowledge co-production, Indigenous knowledge sovereignty and the politics of global environmental change decision-making. Curr. Opin. Environ. Sustain. 2020, 42, 7-14. [CrossRef]

35. Marley, T.L. Indigenous Data Sovereignty: University Institutional Review Board Policies and Guidelines and Research with American Indian and Alaska Native Communities. Am. Behav. Sci. 2019, 63, 722-742. [CrossRef]

36. Schiavoni, C. The global struggle for food sovereignty: From Nyéléni to New York. J. Peasant Stud. 2009, 36, 682-689.

37. McMichael, P. Global citizenship and multiple sovereignties: Reconsituting modernity. In Hegemonic Transitions, the State and Crisis in Neoliberal Capitalism; Atasoy, Y., Ed.; Taylor \& Francis: Oxfordshire, UK, 2009; pp. $23-42$.

38. Folke, C. Resilience: The emergence of a perspective for social-ecological systems analyses. Glob. Environ. Chang. 2006, 16, 253-267. [CrossRef]

39. Gunderson, L.H.; Holling, C.S. (Eds.) Panarchy: Understanding Transformations in Human and Natural Systems; Island Press: Washington, DC, USA, 2002; ISBN 1597269395.

40. Moreton-Robinson, A. Towards a new research agenda?: Foucault, whiteness and indigenous sovereignty. J. Sociol. 2006, 42, 383-395. [CrossRef]

41. Fischer, J.; Abson, D.J.; Butsic, V.; Chappell, M.J.; Ekroos, J.; Hanspach, J.; Kuemmerle, T.; Smith, H.G.; von Wehrden, H. Land sparing versus land sharing: Moving forward. Conserv. Lett. 2014, 7, 149-157. [CrossRef]

42. Cheer, J.M.; Lew, A.A. (Eds.) Tourism, Resilience and Sustainability: Adapting to Social, Political and Economic Change; Routledge: London, UK, 2017; ISBN 1315464039.

43. Gössling, S.; Peeters, P. Assessing tourism's global environmental impact 1900-2050. J. Sustain. Tour. 2015, 23, 639-659. [CrossRef]

44. Saarinen, J. Wilderness use, conservation and tourism: What do we protect and for and from whom? Tour. Geogr. 2016, 18, 1-8. [CrossRef]

45. Marcinek, A.A.; Hunt, C.A. Tourism and cultural commons in the Ecuadorian Amazon. J. Tour. Cult. Chang. 2019, 17, 449-466. [CrossRef]

46. Scheyvens, R. Ecotourism and the empowerment of local communities. Tour. Manag. 1999, 20, 245-249. [CrossRef]

47. Aghazamani, Y.; Hunt, C.A. Empowerment in Tourism: A Review of Peer-reviewed Literature. Tour. Rev. Int. 2017, 21, 333-346. [CrossRef]

48. Timothy, D.J. Contested Place and the Legitimisation of Sovereignty Claims through Tourism in Polar Regions. In Tourism and Change in Polar Regions: Climate, Environments and Experience; Routledge: London, UK, 2010; pp. 288-300.

49. Williams, L.K.; Gonzalez, V.V. Indigeneity, sovereignty, sustainability and cultural tourism: Hosts and hostages at 'Iolani Palace, Hawai'i. J. Sustain. Tour. 2017, 25, 668-683. [CrossRef]

50. Bunten, A. Sharing culture or selling out? Developing the commodified persona in the heritage industry. Am. Ethnol. 2008, 35, 380-395. [CrossRef]

51. Bunten, A. More like Ourselves: Indigenous Capitalism through Tourism. Am. Indian Q. 2014, 34, 285. [CrossRef]

52. Harbor, L.C.; Hunt, C.A. Indigenous tourism and cultural justice in a Tz'utujil Maya community, Guatemala. J. Sustain. Tour. 2021, 29, 214-233. [CrossRef]

53. MacRae, G. Himalayan Agricultures, Ecologies and Local Food Sovereignties. Anthropol. Forum 2016, 26, 262-275. [CrossRef]

54. MacRae, G. Food Sovereignty and the Anthropology of Food: Ethnographic Approaches to Policy and Practice. Anthropol. Forum 2016, 26, 227-232. [CrossRef]

55. Tilzey, M. 'Understanding the World in Order to Change It': What Might Food Sovereignty Look Like? Or, a Normative Political Ecology as Livelihood Sovereignty. In Political Ecology, Food Regimes, and Food Sovereignty; Springer International Publishing: Berlin/Heidelberg, Germany, 2018; pp. 315-350, ISBN 9783319645568.

56. Sen, A. The perspective of Freedom. In Development as Freedom; Anchor: New York, NY, USA, 1999; pp. 13-34.

57. Allison, E.H.; Ellis, F. The livelihoods approach and management of small-scale fisheries. Mar. Policy 2001, 25, 377-388. [CrossRef]

58. Scoones, I. Livelihoods perspectives and rural development. J. Peasant Stud. 2009, 36, 171-196. [CrossRef]

59. Butler, R. The Tourism Area Life Cycle; Channel View Publications: Bristol, UK, 2006; Volume 1, ISBN 1845410254.

60. Hjalager, A.-M. Stages in the economic globalization of tourism. Ann. Tour. Res. 2007, 34, 437-457. [CrossRef]

61. Hunt, C.A.; Stronza, A.L. Stage-based tourism models and resident attitudes towards tourism in an emerging destination in the developing world. J. Sustain. Tour. 2014, 22, 279-298. [CrossRef]

62. Higgins-Desbiolles, F. Sustainable tourism: Sustaining tourism or something more? Tour. Manag. Perspect. 2018, 25, 157-160. [CrossRef]

63. Hall, C.M. Constructing sustainable tourism development: The 2030 agenda and the managerial ecology of sustainable tourism. J. Sustain. Tour. 2019, 27, 1044-1060. [CrossRef]

64. Nyéléni. Declaration of Nyéléni. Available online: https://nyeleni.org/IMG/pdf/DeclNyeleni-es.pdf (accessed on 24 February 2021).

65. Santafe-Troncoso, V.; Loring, P.A. Indigenous food sovereignty and tourism: The Chakra Route in the Amazon region of Ecuador. J. Sustain. Tour. 2021, 29, 392-411. [CrossRef]

66. Warrior, R.A. Intellectual sovereignty and the struggle for an American Indian future. Chapter 3 of Tribal Secrets: Vine Deloria, John Joseph Mathews, and the recovery of American Indian intellectual traditions. Wicazo SA Rev. 1992, 8, 1-20. [CrossRef]

67. Pfeifer, P. From the credibility gap to capacity building: An Inuit critique of Canadian Arctic research. North. Public Aff. 2018, 6, 29-34. 
68. Bernard, R. Research Methods in Anthropology, 5th ed.; AltaMira Press: Plymouth, UK, 2011; ISBN 9780759112414.

69. Weller, S.C. Cultural Consensus Theory: Applications and Frequently Asked Questions. Field Methods 2007, 19, 339-368. [CrossRef]

70. Atran, S.; Medin, D.L.; Ross, N.O. The Cultural Mind: Environmental Decision Making and Cultural Modeling within and Across Populations. Psychol. Rev. 2005, 112, 744-776. [CrossRef] [PubMed]

71. Gatewood, J.B.; Cameron, C.M. Belonger Perceptions of Tourism and its Impacts in the Turks and Caicos Islands. 2009. Available online: https:/ / www.lehigh.edu/ \{\}jbg1/Perceptions-of-Tourism.pdf (accessed on 5 August 2021).

72. Inuit Circumpolar Council Alaska. Food Sovereignty and Self-Governance: Inuit Role in Managing Arctic Marine Resources; Inuit Circumpolar Council Alaska: Anchorage, AK, USA, 2020.

73. Meyer, W.H. Indigenous Rights, Global Governance, and State Sovereignty. Hum. Rights Rev. 2012, 13, 327-347. [CrossRef]

74. Nicol, H.N. From Territory to Rights: New Foundations for Conceptualising Indigenous Sovereignty. Geopolitics 2017, 22, 794-814. [CrossRef] 